\title{
Neoliberalizme Karşı Demokrasi: Ortak Olanı Yeniden Kurmak İçin Mücadele
}

\author{
Democracy against Neoliberalism: The Struggle to Reconstitute the \\ Common
}

Yavuz YILDIRIM ${ }^{*}$

\section{Öz}

$\mathrm{Bu}$ çalışmanın amacı, neoliberalizmin doğrularına sıkışmamış bir demokrasi üzerine inşa edilen yeni siyaset arayışlarını analiz etmektir. Bu doğrultuda harekete geçirilen talepler, daha geniş çerçevede ortak olanı yeniden kurmak yönündeki çabaları sembolize ederler. Çalışmada bireysel tepkilerden kolektif eylemlere geçiş sürecinde gündelik hayatın öneminin altını çizilirken siyasal aktör olarak sıradan insanın gün geçtikçe önem kazandığı vurgulanmaktadır. Dolayısıyla çalışma, ortak olanın yeniden kurulmasında gündelik hayatın şekillendiği mekânsal boyutun önemi üzerine inşa edilmiştir. $\mathrm{Bu}$ çerçevede siyasal olanın ne olduğu, ortak olanın nasıl ele alındığı sorularıyla birlikte açık alanlarda siyaset pratiği konuyu açıklamanın temel noktasını oluşturacaktır. Özne de bu pratik içinde kurulan siyasal süreç olarak görülecektir. Şehir hakkı, bu unsurları bağlayıcı önemli bir kavram olarak ele alınacaktır. Çünkü bireysel olanla kolektif olanın temas ettiği kentsel alanlar, kamusal olanın yeniden düşünülmesinin somutlaştığı noktalardır. Çalışmanın ana argümanı, neoliberalizmin önerdiği piyasacı doğruların karşısında ortak hayatın yeniden şekillendirilmesi yönündeki arayışın, gündelik hayatın içinden doğduğu ölçüde köklü bir hal alacağıdır. Bu şekilde siyasetin sadece devletle ilişkili olduğu görüşün aksine devletin tabandan kurulan bir ortaklık olduğu düşüncesine ulaşlabilir. Neoliberal düşüncenin demokrasi üzerindeki etkisini bahsedilen genişlikte kapsamlı şekilde sorgulayan Nuit Debout, Diem25 ve Kuzey Ormanları Savunması örnekleri somutlaştırıcı alt başlıklar olarak ele alınmıştır. Bu örnekler, gündelik hayat pratiklerini ve taleplerini daha geniş bir siyasal çerçeve ile buluşturmaya çalışan siyasal eylemlerdir. Bunlar neoliberalizmin yönettiği bir demokrasiye karşı, karar-verme mekanizmalarına müdahaleyi yeniden tartışmaya açarak demokrasi kavramının köklerine dönüşünü öngörür. Piyasaların hesap-vermez, uzmanlara dayalı ve teknikleştirilmiş kararalma süreçleri içinde dışarıda bırakılan sıradan insanın yeniden sesini yükseltme çabasıdır. Dolayısıyla temsili demokrasinin sınırlarını ve krizini de ortaya koymaktadırlar. Ortak olanı açık alan ve taban eylemleriyle kurmaya çalışan bu örneklerin yerel, bölgesel ve kıtasal çapta etkiler yarattığı görülebilir. Demokrasi bu bağlamda kendi hayatı üzerinde kolektif eylemler aracılığıyla söz söylemek ve müdahale etmek isteyen bireylerin çabalarıyla kavramsal bir hal almaktadır. Bireysel olanla kamusal arasındaki bağı kurmakta öne çıkan kentsel zeminler, demokrasinin teorisi ile pratiğinin de buluştuğu alanlardır. Ortak olanı coğrafi ve fiziksel paylaşımların ötesinde siyasal bir tartışmanın zemini olarak ele almak,

Yrd. Doç. Dr., Niğde Ömer Halisdemir Üniversitesi, yavuz.yildirim@ohu.edu.tr 
kurulacak alternatifleri daha geniş şekilde düşünmeyi sağlar. Alternatif, var olan başka bir kalıbı kullanmak değil, ortak olanı yeniden kurarak ortaya çıkacaktır. Kentsel alanlar bu açıdan hem somut hem de teorik çabaları göstermek açısından önemlidir.

Anahtar Kelimeler: Neoliberalizm, Demokrasi, Ortak Olan, Kolektif Eylem, Nuit Debout, Diem 25, Kuzey Ormanları Savunması.

\begin{abstract}
The aim of the study is to analyze the new political struggles in the search of a new democracy that is not limited with the neoliberal postulates. These demands symbolize the attempts to reconstitute the common around the people. The study underlines the raising importance of the daily life issues and also the efforts of ordinary people as political subject. Thus, the study is based on the crucial role of the spatial dimension that shape the ordinary life. In this framework the main issues are to analyze the questions like how to define political and how to conceptualize the common. And also, the main focus is the making politics in the open spaces. The subject will be taken as a making process in this kind of the practice. The right to the city concept also will take into account to come together these factors. Because the spaces of the city where connect the individual and the collective ones are the crucial nodes in rethinking the public. The main argument of the study is that the searching of a new democracy beyond the neoliberal rationality will be rooted strongly if it keeps the connection with the daily life struggles. Thus, against the approach that the politics is related with the state only, it is possible to reach that it stems from the common grassroots. Some cases like Nuit Debout, Diem25, Northern Forests Defense that challenge the effects of the neoliberalism on democracy will be given as the examples of this kind of argument. These cases are the political and collective actions that try to make connection the daily life demands and practices with more broaden political issues. They anticipate the regenerate the roots of the democracy concept by rethinking intervention in decision-making mechanisms against a democracy that is ruled by neoliberalism. It is an effort to raise the voice of ordinary people who are left in place between the calculation, the specialization of the markets and the process of operation and decision-making. Therefore, they represent the limits of the democracy and the crisis. The efforts of these actions that grasp the common with the relations in daily life have bigger impacts on political debates. In this line, the democracy is conceptualized as an effort of the people to intervene and make an impact on decision-making process and also their own lives. Thinking the common as the base of a political debate beyond the geographical and physical sharing, it allows to consider the alternatives to be established in a broader way. Urban areas are important in this regard in terms of both concrete and theoretical efforts.
\end{abstract}

Keywords: Neoliberalism, Democracy, Common, Collective Action, Nuit Debout, Diem25, Northern Forests Defense.

\title{
Giriş
}

Neoliberalizm, 1970'lerle birlikte küresel siyasette belirleyici düşünce haline gelmiştir. Kavramın temelinde, sosyal refah devleti kavramına karşı laissez-faire bir kapitalizme geri dönüş fikri vardır (Harvey, 2005). Kamunun küçültülmesi ve piyasanın genişletilmesi yönündeki bu bakış, liberalizm ile muhafazakarlığın birbirine yakınlaşmasını sağlamıştır. Serbest piyasa ve güçlü devlet kombinasyona dayalı neoliberalizm, Washington Konsensüsü olarak anılan kurumlarda somutlaşarak küresel çapta siyasal eğilimleri serbest piyasa ekonomisi üzerinden belirlemektedir (Hardt ve Negri, 2004, s. 
190-193). Diğer bir deyişle siyaseti iktisadi idareye çeviren neoliberalizmin rasyonalitesinin yarattığ1 normaller, "hayatın tüm yönlerini ekonomik optimizasyon mantığına ve malların, değerlerin, hayata dair umutların piyasa tabanlı bölüşümüne" dayanır (Douzinas, 2015, s. 57). Bu süreçte devletlerin şirket gibi yönetilmesi düşüncesi, 1990'larda önce yönetişim daha sonra hesap-verebilirlik ve sürdürülebilirlik gibi kavramlarla güçlendirilerek ilerledi. Bu kavramların temelinde karar alma süreçlerinde konunun muhataplarıyla, çoğunlukla o konuda kurulmuş sivil toplum kuruluşlarıyla görüşerek bir tür katılımcılık sağlamak ve önceki dönemin eleştirilen bürokratik katılığının önüne geçmek düşüncesi vardır. Bürokrasinin tek taraflı aldığı kararların yerine 'paydaş'ların birlikte düşünmesi hedefleniyordu ve böylece meşruluğun zemini yeniden kurulmuş olacaktır Neoliberalizm gittikçe genişleyen bir şekilde kamu politikalarının farklı boyutlarını belirleyen temel doğru haline geldi (Springer, Birch ve Macleavy, 2016; Cahill ve Konings, 2017).

Yakın dönemde kamu siyasasını önemli oranda belirlemeye devam etse de neoliberalizme karşı çıkış yollarının arandığı görülmektedir. Bu arayış, siyasal bir süreçtir ve ortak yaşam alanlarının savunulması ve buradaki ilişkilerin yeniden düşünülmesini beraberinde getirmektedir. Diğer bir deyişle insanlar arası ilişkinin temelleri üzerine sorgulama iş yaşamından yaşanan çevreye kadar farklı alanlarda karar-alma prosedürlerini kapsayacak şekilde genişlemekte ve birbirini etkileyen ilişkisel bir sürece dönüşmektedir. Neoliberalizmin önerdiği piyasacı doğruların karşısında ortak hayatın yeniden şekillendirilmesi yönündeki arayış, gündelik hayatın içinden doğduğu ölçüde köklü bir hal alacaktır.

Ortak olan, herkesin erişimine açı olanı ifade eder ve siyasal bir kavram olarak insanların bir araya gelerek kurduğu alanları içerir. Bir yapı yerine alan yaratmak burada kritik konumdadır. Alanlar, fiziksel ve fikirsel düzeyde bir araya gelinen yerlerdir. Bir araya gelmek, kurucu bir eylemdir çünkü bu eylem diş çevrenin yeniden dizayn edilmesini içerir. Söz konusu kuruculuk gündelik hayatın dayandığı temel doğrulardan yol çıkar. Bu şekilde siyasetin sadece devletle ilişkili olduğu görüşün aksine devletin tabandan kurulan bir ortaklık olduğu düşüncesine ulaşılabilir. Ancak nihai amaç, sadece devleti şekillendirmek değil, hayatı yeniden şekillendirmektir. Böylece kurucu mücadele kavramı gündelik hayatın içine kadar girer.

$\mathrm{Bu}$ çalışmanın amacı, neoliberalizmin doğrularına sıkışmamış bir demokrasi üzerine inşa edilen yeni siyaset arayışlarını analiz etmektir. Bu doğrultuda harekete geçirilen talepler, daha geniş çerçevede ortak olanı yeniden kurmak girişimlerini oluştururlar. Çalışmada bireysel tepkilerden kolektif eylemlere geçiş sürecinde gündelik hayatın altı çizilirken siyasal aktör olarak sıradan insanın gün geçtikçe önem kazandığı vurgulanacaktır. Dolayısıyla çalışma, ortak olanın yeniden kurulmasında mekânsal birliktelikler üzerine inşa edilmiştir. Bu çerçevede siyasal olanın ne olduğu, ortak olanın nasıl ele alındığı sorularıyla birlikte açık alanlarda siyaset pratiği konuyu açıklamanın temel noktasını oluşturacaktır. Özne de bu pratik için oluşturulan bir kuruluş süreç olarak görülecektir. Şehir hakkı, bu unsurları bağlayıcı bir kavram olarak ele alınacaktır. Çünkü bireysel olanla kolektif olanın temas ettiği kentsel alanlar kamusal olanın yeniden düşünülmesinin somutlaştığı noktalardır. Kurucu bir eylemin bireyi ve içinde işlediği yapıyı karşılıklı değiştirmesi muhtemeldir. 
$\mathrm{Bu}$ noktalar bir kentsel meydandan yeşil alanlara ve bir kıtaya kadar uzanan genişlikte düşünülebilir; ortak olanı kuran değerlerin mekanla ilişkisi üzerinden yeniden düşünülmesi yeni bir dünya kurma vizyonuyla beraber ilerler. Diğer bir deyişle, insanların kolektif eylemler aracılığıyla siyasal olanın ne olduğunu sorgulaması ve bu noktada ortak olan duygusunu yeniden yaratmasını anlamak amaçlanmaktadır. Bu süreç, sabit bir uzlaşmaya ulaşmak değil tersine uzlaşılmış varsayılanın sorgulanmasıdır. Çalışma bu hareketlerin gündelik ilişkileri belirleyen en temel unsurlara kadar inebileceğini, büyük söylemler veya meta-politikanın bu tarz mikropolitikalar ve somut sorunlardan doğduğunu vurgulamaktadır. Neoliberal düşüncenin demokrasi üzerindeki etkisini bahsedilen genişlikte kapsamlı şekilde sorgulayan Nuit Debout, Diem25 ve Kuzey Ormanları Savunması örnekleri somutlaştırıcı alt başlıklar olarak ele alınacaktır.

\section{Siyasal Olan ve Açık Alanlar}

Ranciere'in belirttiği gibi (2007, s. 150), siyaset söylenebilene ve görünebilene müdahaledir. Bu müdahale, yerleşik ve sınırlandırılmış olanı sorgulamaya yöneliktir; dolayısıyla siyaset polisin kurulu düzeninin karşısında yer alır. Kabul edilmiş ve sorgulanmaz bir şekilde dağıtılan rollerin sorgulanması, siyasetin yeniden doğuşudur. Dağıtılmış payların ve ilişkilerin kurduğu bir uzlaşma yerine bu ilişkilerin uyuşmazlığını kabul etmek, kurulan ortaklığın sorgulanmasını beraberinde getirir. Diğer bir deyişle ortak olanı kurmak, siyasal bir müdahaledir. Bu müdahale özneler arası siyasal tartışmayı doğurur; devamında siyaseti kurumsallaştırır ve buna bağlı siyasaları yaratır. Dünyanın nasıl değiştirileceği, korunacağı ya da bozulacağı ortak olanın ne olduğu sorusuna verilen farklı cevaplar ve dolayısıyla siyasal olanın nasıl ele alınacağına dair farklı yaklaşımlara bağlı olarak değișir. Kolektif eylemler ve devamında ortaya konan toplumsal hareketler bu minimum zeminlerin nasıl kurulduğu ve oradan hangi siyasetin şekillendirildiği ile ilgilidir.

Siyasal müdahalenin şekillendirdiği ortak olan (commons/ yararlanılan bazı kaynaklarda geçtiği haliyle, müşterekler), "mevcut kaynakların bir kullanıcılar/üreticiler topluluğu tarafından paylaşıldığı, bu kaynakların kullanıcılar/üreticiler demokratik ve yatay yönetim biçimleri ile karar verdiği sosyal sistemlerdir” (De Angelis ve Harvie, 2017, s. 105). Bu sistemlerin işleyişi, siyasal karar-verme mekanizmalarından doğrudan etkilenmektedir. Siyaseti devletin dışında daha geniş çerçevede düşünmek, ortak olanı da sadece devleti kontrolündeki alanların ötesine taşımayı sağlar. Genel olarak diğer insanların kullanımının dışlanamayacağı serbest erişim hakkı olan (yeraltı su havzaları, göller, sulama sistemleri, ormanlar gibi) ortak kaynakları ifade eden bu kavram ekonomi ve siyaset ilişkilerinin karmaşıklaşmasıyla beraber daha geniş bir içeriğe bürünmüştür. Başlangıçta daha çok çevre siyaseti, coğrafya veya ekoloji gibi alanlar üzerinden düşünülen ortak olan kavramı, zaman içinde ekonomi politiğin bu alanlara temas eden alt-alanlarının giderek güçlenmesiyle başlı başına bir çalışma alanı haline gelmiştir. Birey-devlet ilişkisinde seyir değiş̧ikliği, bu değişiklikte ekonomi aracısının belirleyiciliğinin gün geçtikçe artması ve neoliberal düşüncenin güçlenmesiyle diğer iki unsuru belirlemesi, ortak olanın ekonomik gidişata yönelik bir karşı çıkış olarak anlaşılmasını sağlamaktadır. Bu tespit ekonomik indirgemecilik yapmak değil, ekonominin siyaseti belirlerken sosyal ilişkileri göz ardı ettiği tespiti yapmak anlamına gelir. 
Ortak olanı kurmak için müdahale ve mücadele, sosyal etkileşimin temelini oluşturur. Nihai sonuç olmasa da devlet ve onunla ilişkili diğer kavramlar bu etkileşimlerin sonucunda şekillenir. Birlikte yaşamın ve buna bağlı olarak iyi yaşamın nasıl oluşturulacağına dair bir sorgulama, kişiler arası ilişkileri, bunların yaşandığı yerleri ve alanları önemsemek ve üzerine düşünmeyi gerektirir. Bu süreç, yerleşik siyasal doğrular ve kavramlar karşısında yeni bir siyaset arayışıdır. Demokrasiyi yeniden düşünmek, bu şekillendirme politikasını da belirleyecektir. Bu süreç siyasal-dışı bir arayış değil siyasetin alanını genişletici bir çabadır. Kamusallığın oluştuğu ortak olanı piyasa üzerinden değil farklı noktalardan kurmak temel istektir.

Ortak olanın sadece kamu siyasası ve devletle ilgili bir konu olmaması nedeniyle klasik devlet teorilerinin açıklamaları burada yetersiz kalır. Özellikle neoliberalizmin dayandığ liberal devlet teorisi, eleştirilecek temel noktadır. Kamusal olanı özel olanın karşısında dar tutmak isteyen, bireysel etkinliği pazar ilişkilerindeki özgürlüğe dayandıran ve dolayısıyla devleti, mülkiyetin güvenliği ve rıza alarak yönetim olarak daraltan liberal teorinin 18. yüzyılda temellenen bakış açısı, 1970'lerden itibaren kamu işletmeciliği (Radnor vd., 2016) bağlamında güncellenerek yeniden belirleyici konuma gelmiştir. Neoliberalizm, bireysel tercih özgürlüğü ve mülkiyet güvenliği eksenine dayanan liberal devlet teorisinin yeniden tasarlanmış halidir. Neoliberal dönemde birey-devlet ilişkisi, devletin küçülmesini değil piyasayla birlikte işlemesini önerir. Böylece liberal teorinin temellerini atan piyasa-devlet karşıtlı̆̆ değişim gösterir. Sosyal-demokrat ya da kalkınmacı devlet versiyonlarıyla ekonominin rolünü piyasa yönünde belirlemeye devam eden liberal teori karşısında, sınıfsal farklılıkları aşmak için işçi sınıfının önderliğinde yeni bir ilişki düşünen Marksist devlet teorisinin özellikle SSCB ekseninde bürokratik bir işleyişe takılması, neoliberalizmin özgürlük savunusunu canlandırmayı kolaylaştırmıştır. Buna dair alternatif arayışları ve devleti değişen dönemde yeniden anlamlandırmak, 1960’lardan itibaren siyasal teoride önemli bir alanı oluşturur (Jessop, 2016, s. 71; Jessop, 1990, s. 338; Carnoy, 2014, s. 89; s. 153). Devleti sınıfın baskı aracı olarak araçsallaştırmanın ötesinde yeniden düşünmek ve ekonomik, sosyal ve siyasal boyutları birbiriyle temas halinde ele almak önemlidir. Hegemonik ilişkilerin çatışmacı doğasını sadece ekonomik ilişkiler değil kentsel alanlar başta olmak üzere ortak olanı şekillendirecek her noktada aramak Marksist devlet teorisinin de ötesine geçmeyi ve ortaklığı şekillendirirken öncelikle bireysel olanı liberalizmin ötesinde ele almayı gerekli kılar. Böylece birey, özgürlük ve kamusal ortaklık, ekonomiyi de kesen ancak tabandan kurulan eylem birlikteliğine dönüşür. Devleti değil bireysel ilişkileri merkeze alan siyasal bir bakış açısının gelişimini sağlamak için kentsel alanlar önem kazanır.

Kentsel alanlar ve şehir, modern dönemde insani paylaşımların kurulduğu ve kamusal olanı sembolize eden temel coğrafi zeminlerden biridir. Burjuva düşüncesinin ve pazar ilişkilerinin kent merkezli doğması bu sürecin temelidir. Burjuvazinin ve piyasa ilişkilerinin genişlemesiyle birlikte ortak olanların kırsal varlıklar olduğu algısı yerini kentsel mekân ve pratikleri kapsamaya doğru evrilmiş ve böylece ekolojik müşterekler kadar kentsel müşterekler de bu konunun gündemi haline gelmiştir (Gidwani ve Baviskar, 2017, s. 198-200). Çünkü şehirler tarihsel, sosyal, kültürel güçleri bünyesinde barındırdıkları için iktidar ve güç ilişkilerinin taşıyıcısıdırlar ve bu özellikleriyle modern dünyadaki insani gelişimin de sembolüdürler (Parker, 2011, s. 170). Karar alıcı noktalara 
yönelik baskı ve talepler, güç ilişkilerini görünür kılar. İnsani eylemlerin kuruculuğu, kurumların yasallığı ve uygulamalarındaki etkileşimi belirler. "Kentleşme, kapitalizmin tarihi boyunca sermaye ve emek fazlasının soğrulmasını sağlayan kilit yöntemlerden biri olagelmiştir” (Harvey, 2013, s. 88). Bu tarz güç ilişkilerinin görünür kılınması, kolektif eylemlerin çabalarında netleşir. $\mathrm{Bu}$ açıdan şehir üzerinden ortak olanı düşünmek, sıradan insanın ve gündelik yaşamın siyasete etkini ortaya koymak açısından önemlidir. Stavrides'in (2016) belirttiği gibi ortak alanı açmak ya da genişletmek, paylaşılan kültürün ve yaşamsal ortaklıkların yeni biçimlerini yaratmak için ortaklaşmanın gücünü açıkça ifade etmektir. Kente dair ortak alanları yaratmak, korumak ve geliştirmek siyasal taleplerin merkezinde yer alan bir konumdadır. Siyasal hakları şehirde geliştirmek, kentin içinde ve kentsel bir mücadelenin dayanak noktalarını oluşturur.

Kentteki siyasal ve ekonomik hakları tabandan ilerleyecek şekilde düşünerek ortak olanı kurmak hedefinde, şehir hakkı düşüncesi belirleyici konumdadır. Lefebvre’ye göre (1996) bir "haykırış ve talep" olan şehir hakkı, insanın kendi kurduğu yapıların üzerindeki denetimi ve etkisine dairdir. Lefebvre şehir hakkı kavramının vatandaşlık idealinin, sadece devlet tarafından tesis edilmiş kurumsal vatandaşlık değil, sınırlandırılmamış akışların kurduğu gündelik sosyal pratikler aracılığıla herkesi sosyal ve mekansal olarak kapsamasıyla ilgili olduğunu belirtir (1996, s. 158). Lefebvre üzerinden şehir hakkını düşünmek, kentsel alanın toplumsal yapılanmasını ve geleneksel vatandaşlık anlayışını genişletir ve bireyi bir şehir sakini olarak ele almayı sağlar (Erdi-Lelandais, 2014, s. 7-8). Bu süreç hem kendi aktivitelerinin zaman ve mekanını yaratmak hem de bireylerin kendi merkezlerini yaratması hakkıdır. Harvey (2008) bu üretkenliğin yeni bir yaşam biçimi üretmekle eş değer olduğunu belirtir. Böylece şehir, sadece fiziksel bir mekân olmanın ötesine geçer. Harvey’e göre şehir hakkı, "şehrin barındırdığı kaynaklara bireysel veya kolektif erişim hakkı" ve "şehri değiştirme ve yeniden icat etme hakkı" boyutlarını içinde barındırır: "Kendimizi ve şehirlerimizi şekillendirmek ve yeniden şekillendirmek insan hakları için en değerli fakat bir o kadar da ihmal edilmiş bir olanıdır” (Harvey, 2013, s. 66). Ancak bu şekillendirme süreci giderek özel ve yarı-özel çıkar gruplarının, şehri gittikçe kendi ihtiyaçları ve arzuları doğrultusunda şekillendirme gücüne sahip, küçük bir siyasi ve iktisadi elitin eline geçmektedir (Harvey, 2013, s. 67). Dolayısıyla şehir hakkı, belli azınlığın kontrolünü engellemek için farklı olma hakkıyla birlikte düşünülmelidir; çünkü şehir farklılıkların karşılaşmasıdır (Butler, 2012, s. 152). Farklı seslerin yükselttiği hak talepleri, bu çerçevede gelişen kolektif eylemler şehrin şekillendirilmesinde ve yeni bağlantılar kurulmasında etkili olur. Dolayısıyla şehre dair taleplerin ifade edilmesi, bireylerin doğrudan katılımı açısından demokratik zeminin inşasında önemli ve aynı zamanda farklı boyutları içinde barındırdığı için kapsayıcıdır. "Müşterek mekân, bir topluluk tarafından sürekli yeniden yaratılan ve bu topluluğun ve bu topluluğun eşit kabul edilen üyelerinin katılım süreçleriyle örgütlenen mekandır” (Stavrides, 2017, s. 245).

Bu şekilde park, sokak ve meydanlar gibi açık alanların nasıl şekillendirileceğine dair tartışmalar, ortak olanın ne olduğunun bir göstergesi haline gelir. Bunlar bireylerin gündelik hayatına doğrudan temas ve diğer insanlarla direkt iletişim kurmayı sağlayan yerlerdir. Şehirde ortak olanın korunması, diğer insanlarla paylaşılan alanların korunmasıyla başlar. Ortak alanların ticari bir mantığa karşı kamusal bir bakışla değerlendirilmesi gereklidir. Neoliberalizm kamu 
siyasasına şirket gibi düşünmeyi ve kar odaklı analizleri dayatsa da kent sakinlerinin burada karar-alıcı noktalara uygulayacağı baskı ve pratikler önem kazanır. Çünkü bu alanlar içinde insani ilişkilerin nasıl kurulacağı, genel olarak siyasetin nasıl işleyeceğini belirleyecektir. Ortak alanların korunması, insan hayatının korunması anlamına gelecektir.

$\mathrm{Bu}$ süreç, birlikte olmak bakımından topluluk ve bağl1lıkların yeni sınırlarını üretmek için şehre dair alternatif kullanımlarını mümkün kılmak anlamına da gelir (Agustin, 2015, s. 50). Söz konusu alternatifler, birlikte düşünmeyi ve eyleme geçmeyi barındırırken pratik hayata dair temel sorunların çözümünü sağlar. Böylece bireyler yeni temas noktaları geliştirilir. Gündelik pratikler bu açıdan önemlidir çünkü kendi hakları etrafında siyasal fikirleri deneyimleme kültürü, öğrenme ve iş birliği ilişkilerini kurar ve geliştirir (Yates, 2015). Karşlıklı etkileşim, yeni deneyimler üretecektir. Bu üretim, aynı zamanda öz-yeniden-üretimi, yeni bir tarz bireyselleşmeyi doğurur. Ortak olanını kurucu fikri, direnen özne olarak bir özneleşme mantığını şekillendirir (Zevnik, 2015). Yeni özne, bir yapı içinde sadece kendine sunulanı devam ettiren değil, kendi alanını kurabilen yaratıcı kapasitesini ortaya koyabilen bir potansiyeli taşır. Ortak olanın üretimi, potansiyelini farklılıkların çoğulluğunda bulur. Bu çoğulluk sürekli bir mücadeleyi içerir (Curio, 2010, s. 78). Ortak olan, tekillik ile çokluk arasında yeni bir ilişki kurumudur. Boş evrenselin tersine soyut özneye farklılıkları indirgemez. Çoğulluğu doğal değildir; tekilliği bireysel değildir; ortak olan evrensel değildir (Gigi, 2010, s. 365). Müşterek yeni diller, dayanışmalar, toplumsal ve mekânsal pratikler mücadele ilişkileri ve repertuarları üreten direniş anlarıyla doludur (Chatterton, 2017, s. 205). Bu alanın, kolektif eylem ve toplumsal hareketlerle ilişkisi bu nokta üzerinden kurulur. "Ortak çıkar devlet kontrolünde soyutluk kazanan bir genel çıkar değil, çokluk tarafından demokratik biçimde yönetilen bir kamusal çıkardır” (Hardt ve Negri, 2004, s. 224). Bu bağlamda ortak olan, kamusal olanın temelini oluştururken bunun nasıl şekillendirileceğine dair ortak eylemler de yeni birlikteliklerin, toplulukların ve ağların oluşumunu sağlar. Devamında yeni siyasal öznelerin oluşumu gerçekleşir. Bu yazının iddiası da odur ki, sıradan insanın kendi hayatına ve ortaklık kurduğu diğer insanlarla kesişim kümelerine dair faaliyetleri, onu siyasal özne haline getirir. Böylece hayatı üzerinde söz sahibi, hayatının dinamiklerini kontrol edebilen bireylere dönüşme ihtimali ortaya çıkar. "Ortak payda yeni bir egemenlik biçimine, demokratik bir egemenliğe işaret eder” (Hardt ve Negri, 2004, s. 224).

De Angelis’e (2017, s. 273) göre "toplumsal hareketler, kendilerinin bir parçası olan öznelerin yaşamlarını ve toplumsallık biçimlerini yeniden üreten bir müşterekler zemini olmaksızın kurulamaz." De Angelis, toplumsal hareketlerin siyasal devrimiyle müştereklerin toplumsal devriminin geliştirilmesiyle köklü bir değişimin mümkün olacağını vurgular. Kolektif eylemler aracılığıyla kurulan toplumsal hareketler belli bir konu ya da yasa üzerine odaklanacağ gibi genel değişim isteklerini (örneğin daha fazla ve açık demokrasi) yansıtır. Hareketler özel ile genel arasında, bireysel ile kamusal arasında bağ kurar. Temel hedef siyasal bir devrim ya da iktidar kaynaklarını ele geçirmek olmayabilir. Dolayısıyla De Angelis'in tespitini ortak olanın şekillendirilmesinde birlikte ve kapsamlı mücadelenin önemi olarak ele almak gerekir. Bu süreç ortak duyunun (common sense) yaratılmasıdır. Ortak duyu, nihai uzlaşma ve bozulmayacak bir fikir birliğine varmaktan ziyade karşılıklı etkileşim ve çekişme pratiklerini içinde barındıran 
dinamik bir süreçtir. Bu dinamizm, ekonomik, siyasal ve kültürel zeminlerin birbirini etkilemesinden kaynaklanır.

Della Porta’nın (2015) belirttiği gibi ortak olanın ve (metalaşmanın/commodification değil) ortaklaşmanın (commonification) yeniden oluşturulması düşüncesi, kamu hizmetlerinin katılımcı yaklaşımla birleştirilmesi için bir köprü görevi görür. Neoliberal dönemin ticarileşme, serbest piyasa doğrularıyla düşünme ve metalaşma yaklaşımları karşısında kamusal düşünce önemli derecede gerilemiştir. Bu durum kamusal hizmetlerin de piyasa mantı̆̆ıyla verilmesinin önün açmıştır. Yönetimden yönetişim düşüncesine, kamu yönetiminde kamu işletmeciliğine geçiş bu değişimin kavramsal karşılıklarını ifade eder. Uzmanların demokrasisi yerine herkesin demokrasisini savunmak ise bu değişime direnişi gösterir. Metalaşmanın, özelleştirmenin, bireyselleşmenin karşısında kamusal olanın, herkesin olanın ve dolayısıyla halkçı düşüncenin savunulmasıdır. Avrupa’da son dönemlerde yükselen "gerçek demokrasi” arayışı, kemer-sıkma karşıtı protestolar ve bu hareketlerin devamında oluşa yeni parti ve koalisyonlar (Podemos, Syriza vb. ) bu düşüncenin somut örneklerindendir. Bu hareketlilikler, esasında neoliberalizmin yönettiği bir demokrasiye karşı, karar-verme mekanizmalarına müdahaleyi yeniden tartışmaya açarak demokrasi kavramının köklerine dönüşünü öngörür. Piyasaların hesap-vermez, uzmanlara dayalı ve teknikleştirilmiş karar-alma süreçleri içinde dışarıda bırakılan sıradan insanın yeniden sesini yükseltme çabasıdır. Dolayısıla temsili demokrasinin sınırlarını ve krizini de ortaya koymaktadırlar.

Böylece ortak olanı şekillendirmek, demokratik bir siyasetin önünü açmayı da sağlar. Tartışma "nasıl bir demokrasi" ve "sıradan insan demokratik hak olarak karar alma süreçleri ve yaşadığ 1 coğrafyaya müdahale imkanına nasıl erișecektir” sorularının cevabının aranmasına gelmektedir. Esasen son 20 yıl içinde, küreselleşme-karşıtı hareketin başlattığı ve devamında Arap Baharı, İşgal Et Hareketi gibi küresel etkiler yaratan eylemliliklerde ilerleyerek güçlenen bu tartışmayı anlamlandırmak, siyasal teorinin ana gündemlerinden olmuştur. Çünkü bu konu, demokrasi ve vatandaşlık gibi kavramları ve siyasetin ne olduğuna dair kapsamlı eleştirileri içinde barındırırken bahsi geçen eylemleri anlamak için farklı kavramları bir arada düşünmeye sevk etmektedir (Wood, 2017; Gerbaudo, 2017). Demokrasinin yeniden ele alınışında şehirdeki aktivizmin ve protestoların önemli bir aracı olduğu; yeni bir demokrasi anlayışının bu eylemlilikler üzerine kurulacağı düşüncesi yakın zamanda güçlenmektedir (Purcell, 2008; 2013). Bu açıdan söz konusu çaba doğrudan eylem açısından anarşizmi ve özellikle otonomi kavramını, otonomizm geleneğini önemsemektedir (Roos ve Oikonomakis, 2013). Bununla beraber siyasetin eski kurumsal ve yerleşik temelleri üzerinden işleyemeyeceğine dair geliştirilen post-siyaset (Dikeç, 2005; Swyngedouw, 2011) ve post-demokrasi (Crouch, 2004) gibi kavramlar bu süreçte sıklıkla kullanılmaktadır. Bu tartışmalar, liberal demokrasilerin krizi içerisinde 1930'ların ve 1970’lerin geçiş dönemini hatırlatırcasına yeni siyasal zeminlerin yükselişine tanıklık edeceğimiz izlenimini vermektedir. Eski ideolojilerin önemli ölçüde yıpranması ve eleştirilmesiyle teori ile pratik arasında kurulacak yeni bağın nasıl gelişeceği farklı açılardan analiz edilmektedir. Yakın siyasal teorinin odaklandığı temel sorulardan olan liberal demokrasinin krizinin nasıl aşılacağı, yeni bir kurucu aktörün hangi temel noktalardan kurulacağı, kısacası yeni bir kurucu siyasetin ekseni genel bir tartışma konusudur (Douzinas, 2015, s. 174-192). Burada sosyal demokrasiye geri 
dönüş ya da devlet merkezli bir sosyalizm yerine, taban hareketlerine dayalı ve aktivizmin içinde şekillenen bir demokrasinin hedef olduğu vurgulanabilir. Demokratik eylemi yeniden düşünerek ortak olanı tabandan şekillendirme yönündeki çabaları ele alan bu çalışma da bu yöndeki analizlere bir katkı düzeyindedir.

\section{Yatay Hareketlerde Ortak Olanı Kurmak}

Kentlerin kolektif eylemin zemini ve birleştiricisi olması yeni bir durum değildir. Fransız Devrimi'nde, 1871 ya da 1968'te Paris'in rolü akla gelen ilk örnek olabilir. Keza Prag, Berlin, Tianenmen Meydanı çeşitli direniş hareketleriyle özdeşleşmiş ve sembolize olmuş yerlerdir. Dünya Sosyal Forum'unun oluşum sürecinde Porto Alegre ya da Zapatistalar için Chiapas önemi ortadadır. Kentlerin ortak olanı şekillendirme sürecinde demokratik taleplerin yükseltildiği en geniş zemin olarak siyasi ve coğrafi önemi küreselleşmenin etkisi, kentler arası etkileşimin artması fiziksel akışkanlığın ve bilgi paylaşımının hızlanmasıyla daha da öne çıktığı görülmektedir. Arap Baharı sürecinde Tahrir Meydanı, İşgal Et eylemlerinde Zucotti Park’’n, Öfkeliler Hareketinde Puerta del Sol'un isimleri eylemin içeriği ve talepler kadar öne çıkmıştır. Fransa'da yakın zamanda gelişen Nuit Debout hareketi de bu eylem tarzının devamıdır. Bu hareketler daha geniş çapta demokrasiyi yeniden düşünme çabalarına ilham verir ve Avrupa'daki demokrasi mücadelesini pratik anlamda destekler.

Avrupa'da son dönemdeortaya konan kolektif eylemlerin önemlibirkısmıneoliberalizm karşıtlı̆̆ında ortaklaşmaktadır. Tepkilerin temelinde küreselleşmenin getirdiği sonuçların eleştirisi yatmaktadır. Küresel piyasalara uyumlu bir siyaset geliştirmek bu dönemin normalini oluşturmuştur. Piyasaların ulusal egemenlik ve demokrasi gibi kavramlar karşısında rasyonel olanı temsil ettiği düşüncesiyle, siyasetin doğrularının ekonomiyle uyumlu hale getirmek 2000’lerin başından bu yana gelişmekte olan bir çizgi olsa da bir yandan da yoğun eleştirilere maruz kalmaktadır. Piyasaların ve onun yönlendirici aktörlerin demokratik denetimden uzak oluşu, ortaya çıkan gelir adaletsizliği, çevrenin bozulması ve kamusal olanın özel karşısında geriletilmesi gibi sorunların çözümsüz kalmasıyla kitlelerin alternatif çıkış yolları aradığı görülebilir. Eylemlerin temel talebi, neoliberalizm karşısında demokrasiyi sadece bir prosedür olarak görmenin ötesine geçmektir. Demokrasi, sadece liberal demokrasinin temsili ve parlamenter düzeni şeklinde değil ortak hayatı yeniden kurmak adına temel prensip olarak ele alınmaktadır. Karar alma noktasında daha fazla söz hakkı isteyen kitleler, yönetilen değil yöneten konumda aktif bir siyasi özne olmayı talep etmektedir. Aynı zamanda bu eleştiri, içe kapanmacı aşırı-sağı̉n yükselişine karşı ortak olanı sosyal ve dayanışmacı bir çerçevede ele almayı da olanaklı kılar.

“Başka bir Avrupa Mümkün” sloganıyla Avrupa Sosyal Forumu çatısı altında 2002'den 2012'ye kadar olan süreçte bir araya gelen demokrasiyi genişletme yönlü toplumsal hareketler (Yıldırım, 2013), her ne kadar aşırı-sağın söylemsel gücü karşısında daha geri planda kalsalar da, kendilerine yeni yollar aramaktadırlar. Blockupy, Agora 99 gibi yatay yapılanmalar (Yildırım, 2015) kadar Syriza, Podemos gibi siyasi parti oluşumları da bu süreçle doğrudan ilişkiliydi. Yunanistan'da 
kemer-sıkma karşıtı gösterileri yönlendiren eylemlerin desteğiyle iktidara gelen Syrizảnın beklenen tavrı gösterememesi ile oluşan Diem25 (Democracy in Europe Movement 2025) hareketi de neoliberalizme teslim olmayan sosyal bir Avrupa için yeni bir ekonomi-politik geliştirmek için yola çıktı. 2016 içinde Fransa'daki çalışma yasası değişikliğine karşı yürütülen Nuit Debout hareketi de yine tabandan yükselen yeni hareketlerin en somut örneklerindendir. Bu çerçevede ekonomik tartışmaları demokratikleştirmek, diğer bir tabirle karar-alma mekanizmasında tabanın daha çok sesini duyurmak için gerçekleştirilen kolektif eylemlerin ve bunların dönüştüğü toplumsal hareketlerin seyrini anlamak, günümüzde Avrupa siyasetini anlamak için önem teşkil etmektedir. Çünkü hareketler, ekonomi temelli bir birlik ve neoliberal hegemonyanın karşısında farklı bir ortaklık ve kamusallık yaratmak amacındadır.

\section{Diem25}

2008 krizi ve sonraki süreçte Yunanistan, kemer-sıkma politikalarına ve AB’nin ekonomik yaptırımlarına karşı tepkilerin en yoğun olduğu ülkelerden biriydi. Yunanistan’ın merkez sosyal demokrat ve muhafazakâr partileri karşısında toplumsal hareketlerin desteğini alarak büyüyen Syriza’nın iktidar yürüyüşü (Badiou, 2015; Yıldız, 2015), AB’nin ekonomi politikalarına muhalefet zemininde yükselse de iktidarının ilk günlerinden itibaren bu iddialarını yerine getiremedi. Çeşitli toplumsal muhalefet eksenlerini bünyesinde barındıran (Sönmez, 2015) Syriza, ekonomik kriz politikalarına karşı çıkan söylemiyle 2015 genel seçimlerinde iktidar oldu ancak kısa süre içinde hareketin/partinin öncülerinden Yannis Varoufakis’in, söz konusu karşı çıkışın pratikte nasıl uygulanacağı yönündeki ayrışma neticesinde, partiden ayrılmasıyla güç kaybetti. Ancak Syriza’nın zaferi sürecindeki tartışmalar, alternatif arayışlarının hızlanmasını sağladı. Arayışların ekseninde, AB’nin direktifleri ve özellikle AB Merkez Bankası’nın kontrolü dışında krizden çıkış seçenekleri ve bu süreçte demokrasinin ikinci plana atılmaması düşüncesi yatıyordu. $\mathrm{Bu}$ noktada Yunanistan krizi sonrası "alternatif Avrupa” düşüncesini hızlandıran iki inisiyatif oluştu: Avrupa için B Planı (Plan B) ve Avrupa'da Demokrasi 2025 Hareketi (Democracy in Europe Movement 2025 / Diem25). Plan B, 2015 yazında oluşturuldu ve ilk toplantısını Ocak 2016'da Paris’te düzenledi. Birkaç ay sonra, 9 Şubat 2016'da Berlin'de Diem25 kuruldu. Yeni başlayan bu girişimler öncelikle siyasetçiler tarafından ilerletildi ancak AB kurumlarıyla sınırlı kalmayacak bir çerçevede sivil toplum toplumsal hareketlerin desteğine açık olduklarını belirttiler. Hareket ismini, "Carpe Diem” (Anı Yakala) sözünden hareketle şekillendirdi. Ancak bu sözün romantik değerleri kadar hedeflerinin gerçekçi oluğunu da israrla vurguladılar.

Avrupa fikrine sahip çıkan ancak $\mathrm{AB}$ projesini desteklemeyen, yerine Avrupa'yı demokratikleştirmeyi öneren Diem25 kendisini bir siyasal hareket olarak tanımlamaktadır. Bir parti ya da partiler koalisyonu değil, diğer toplumsal hareketlerden esinlenen bir hareket olarak öne çıkmaktadır. Bu doğrultuda bir yandan yerel hareketler temelli ulus aşırı bir hareket olmak öte yandan var olan hareketlerin yetersizliğini vurgulayıp bu mücadelelerin gerçekleşmesini sağlayacak bir hareket olmak şeklinde iki yol izlenebilirdi. Diem25 diğer hareketlerin yerine geçmeksizin, bu hareketleri yeni bir aktöre dönüştürecek ulus aşırı bir ağ kurmayı hedeflemektedir (Agustin, 2017). 
Diem25 hareketi eski Syriza üyesi ve Yunanistan Maliye Bakanı Yannis Varoufakis’in öncülüğünde kuruldu. B Planı’nın tersine sadece tartışmayı destekleyecek siyasal alanlar yaratmak için değil, yeni bir aktör olmak için yola çıktı. Berlin'deki toplantılarının ardından 19 dile çevrilerek yayınlanan bir manifesto yayınlandı. Manifestoda, Avrupa halkı bir aktör olarak hesapsorulamaz teknokratlardan Avrupa’nın kontrolünü geri almak ve Avrupa'da değişimi başlatmak vurgusu yapılmıştır. Böylece aktif rolü, kurumlara değil sıradan Avrupalıların eylemliliğine vermiştir. Demokratik bir Avrupa için halklar arasında onları yetkilendiren yeni bir ortaklık kurulmasını öneren Diem25 bireyleri, iş yerlerini, bölgeleri ve ülkeleri, ekonomik yapıların karşısında güçlendirmeyi önermektedir. Dayanışmacı ve sosyal bir Avrupa, iklim değişikliğine karşı çevreci değerleri de merkezine almaktadır. "Avrupa için İlerici Gündem” başlıklı programları, bu alternatifin detaylarını içermektedir (diem25.org, 2016). Manifesto AB'nin, Avrupalıların paraları, toplulukları, çalışma koşulları ve çevresi hakkında demokratik kontrol uygulanmasını engellediğini vurgulamaktadır. Manifesto'ya göre bu noktada yapılacak tercih, özgün bir demokrasi ile sinsi bir ayrışma arasındadır. Ayrışma tercihi, sadece demokrasinin değil, paylaşılmış refahın da sonu olacaktır. Manifesto, acil önceliğin karar verme sürecinde tam şeffaflık ve AB kurumlarının yeniden düzenlenmesi olduğunu belirtirken orta vadede hedefin yerel, bölgesel ve ulusal meclislerin gücüne saygı göstererek Avrupa çapında yeni bir meclis oluşturmak olduğunu belirtmektedir. Bu doğrultuda tasavvur ettikleri Avrupa'yı demokratik, şeffaf, ortak değerlerde birleşik, gerçekçi, merkezsiz, çoğulcu, eşitlikçi, sosyal, ekolojik, yaratıcı, barışçı ve özgürlükçü sıfatlarıyla tanımlamaktadır.

Diem 25 bu niteliğiyle ulusal politikalardan çok enternasyonalist bir söyleme ağırlık vermektedir. Avrupalılar için ortak olanı birlikte yürütecekleri bir projeye dayandırmaktadır. Bu doğrultuda yerel ve somut mücadelelerin birbirine eklemlenerek yeni bir bütün yaratacağını öngörmektedir. Diem25, AB’nin Margaret Thatcher'dan miras kalma ve neoliberalizmin mottosu haline gelmiş TINA (There is No Alternative/Alternatif Yok) düşüncesinin yansıması olarak kurulduğu eleştirisiyle, yeni bir alternatif yaratma isteğindedir.

Varoufakis, Küresel Minotaurus (2015) adlı çalışmasında 2008 krizinin nedenler ve sonuçları üzerine iktisadi analizler yapmıştır. Bununla birlikte meselenin finansal piyasaların fetişleştirilmesi olduğu teziyle, demokratikleşmeyen piyasa ilişkilerinin iktisadi yollarla çözülemeyeceğini vurgular. Neoliberalizme yönelik cevap ulus-devlet sınırlarına geri dönüp, bizim halkımız ve ötekiler arasında ayrım yapmak değil, ilerici (progressive) bir uluslararası birliktelik kurabilmektir (Varoufakis, 2017). Diğer bir deyişle küreselleşmenin getirdiği sermaye akışlarına karşı yine küresel bir demokratik tavır almak gerekliliğini öne sürmektedir. Esasen bu tavır, Dünya Sosyal Forumu’nun kuruluş sürecinden beri var olan karşı-küreselleşme çizgisinin devamı olarak görülebilir.

\section{Nuit Debout}

Fransa da 2016 yılını neoliberalizm karşıtlığı noktasında hareketli geçirdi. Tartışmaların merkezinde Çalışma Bakanı’nın adına atıfla El Khomri Yasası olarak bilinen Çalışma Yasası 
değişiklikleri vardı. Taslak, 17 Şubat 2016'da Meclis'e sunuldu ve yoğun protestolara rağmen 8 Ağustos 2016'da yasalaştı. Yasa, Fransa Çalışma Hukuku’nu, işsizliği azaltmak adına emek piyasasını daha esnek hale getirecek şekilde düzenlemeyi amaçlamaktaydı. Değişikliklerle işten çıkarmalar kolaylaşırken, çalışanlara yapılan ek ödemelerde de kısıtlamaya gidildi. CGT sendikasının özellikle karşı çıtığı "yasanın en önemli özelliği işçi işveren görüşmelerini merkezi olmaktan çıkarması, sektör düzeyinde değil, işyeri düzeyindeki toplu görüşmeleri özendirmesi ve bu görüşmelere öncelik vermesiydi. Böylece işyerlerine içinde bulundukları ekonomik koşullara göre esneklik sağlanması amaçlandı” (Şakiroğlu, 2016a). Yasa nedeniyle Fransảnın Sosyalist Partili Başkanı François Hollande ve Başbakan Manuel Valls, toplumsal muhalefetin yoğun eleştirileri altındaydı. Bu yasa, partinin solla ilişkisine dair devam eden eleştirileri bir nebze daha ileri taşıdı.

Yasanın görüşüldüğü dönemde, Fakir isimli dergi tarafından 23 Şubat’ta organize ettiği bir etkinlikte bu yasanın protesto edilmesi fikri gelişirken 31 Mart’ta eylemler meydan işgaline kadar büyüdü. “Tüm Fransa’da bir milyon iki yüz binden fazla göstericinin katıldığ 31 Mart” eylemi, bir tür genel grev olarak işçi sendikalarının protestolarını aşan bir niteliğe büründü. Böylece bu hareket "genel öfkenin yaygın bir dinamiğinin ve arayış içerisindeki farklı mücadelelerin az ya da çok eş anlı olarak yeterli bir ifade bulduğu bir odak haline geldi. Böylece işçi hareketinin geleneksel kadrolarının dışında mücadelenin ikinci dayanağı doğmuş oldu” (Birnbaum, 2016). 31 Mart grevi sonrasında bu eylemler Nuit Debout (Gece Ayakta) olarak anılmaya başlandı.

Dergi yöneticilerinden Frederic Lordon, Nuit Debout eylemlerinin "politik uykudan uyanma" adına çok önemli olduğunu söylerken aynı zamanda ayakta/uyanık olma ifadesi, siyasal bir direniş anlamına geldiğini vurgulamaktadır. Geniş katılımlı, öz-örgütlenmeye dayalı bir siyasal eylem olarak Nuit Debout kamusal bir forum imkanı sağlaması açısından önemlidir (Brand ve Gupta, 2016). Bu eylem tarzı Occupy, Syriza, Podemos eylemlerinde edinilen deneyimlerin bir adım daha öteye taşınmasını sağlarken gençlerin bu eylemlerde siyasallaşmasının yolunu açtı (Pleyers, 2016). Hareket, iş yasasında öngörülen değişikliklere karşı ortaya çıksa da kısa sürede diğer Avrupa toplumlarını da etkileyen konulara doğru genişledi. Katılımcılar feminizm, ırksal eşitlik, antifaşizm, çevrecilik, demokrasi gibi başlıklarda kendilerini ifade etti. Bu alanlardaki mücadelelerin birlikte ilerlemesi fikri vurgulandı. Yerel bağlamlarda, farklı şehirlerde toplantılara ve doğrudan demokrasi uygulamalarına ilham verdi. Her yerel hareket, kendi yapısını, çalışma gruplarını, hedeflerini, eylemlerini yarattı. Özellikle göçmenlere destek konusunda eylemler gerçekleşti (Pescinski, 2016). Eylemlerde genel olarak Fransảın siyasal elitlerine ve Sosyalist Parti hükümetine yönelik eleştirilere yoğunlaşıldı. Troçkister, anarşistler, ve anti-kapitalistler gibi farklı sol eğilimli aktörler bu protestolarda yer aldı. Özellikle yaklaşan seçimlerde muhalif çevrelerin oy verecek bir adayının olmaması önemli eleştirilerden birini oluşturdu. Diğer bir deyişle Nuit Debout Fransa'da hissedilen siyasal ve ekonomik bir rahatsızlı̆̆ı yansıttı. Fransa demokrasinin krizi bu eylemlerde kendini gösterdi.

Haski’ye (2016) göre Nuit Debout, internet çağında Mayıs 68'le bazı benzer özellikle sahip ancak önemli farklar da var; 1968'in gençleri, savaş-sonrası ekonomik kalkınmanın muhteşem 30 
yılına doğru gelirken muhafazakar bir toplumu eleştirmişlerdi, şimdi ise temsili demokrasinin işleyişiyle uyumsuzluk, ekonomik çöküş ve yüksek işsizlik oranlarıyla muhataptırlar. 1968'te olduğu gibi, orta-sınıf ailelerin çocukları sokaklarda ancak genç işsizliğin sonuçlarıyla henüz tam olarak karşılaşan kişiler de değildir. Bu durum Nuit Debout katılımcılarının kendi arasında bir kutlama yapma şeklinde zayıflı̆̆ı olarak görülebilir (Haski, 2016).

Katılımcılar, yapılan söyleşilerde hareketin başarısız olma ihtimaline rağmen bu eylemlerin gelecekte başka akımları ortaya çıkaracağını ve vatandaş olarak asıl gücün kendilerinin elinde olduğunu bileceklerini belirtmişlerdir (tr.euronews.com, 2016). Eşitlik, özgürlük, kardeşlik gibi tüm Avrupa’yı saran ideallerin doğduğu coğrafya olan Fransa'da vatandaşların yaşam tarzlarını değiștirmek isteyen bir yasaya karşı direniş geliştirirken, devletin aynı düzeyde tolerans göstermediği ortadadır (Wadham, 2016). Eylemciler bir süre sonra meydandan polis gücüyle uzaklaştırılırken, Fransız sendikaları yaptıkları grevlerle gençlerin başlattığı protestolara destek vermişti. Ancak Nuit Debout eylemlerinde gösterilerde sadece polise karşı değil aynı zamanda sendika yönetimlerine karşı da muhalefet vardı (Birnbaum, 2016). Eylemler Fransa’da ve Avrupa genelinde sendika, parti ve toplumsal hareketler arasındaki ilişkilerin sorgulanması açısından önemli bir örnek olay haline geldi.

Sokaklarda yürüyen protesto Parlamento'ya da yansıdı ve Sosyalist Parti içinde dahi eleştirilerin yükselmesiyle Temmuz 2016 'da normal oylama prosedürü uygulanmadan ve oylanmadan Parlamento’dan geçti. Anayasa’nın 49/3 maddesinin işletilmesi, yasanın eleştirilerden kaçırılması için bir yol olarak görüldü ve bu da siyasi krizi derinleştirdi (Birnbaum, 2016). Anayasa Mahkemesi'nin yasayı iptal etmesi için imza kampanyaları düzenlendi ancak Mahkeme’nin onaylamasının ardından Ağustos 2016'da da o dönemki Başkan Hollande’ın imzalamasıyla yürürlüğe girdi. Sendikalar, yasanın yürürlüğe girmesinin ardından protestolarına devam etti. Hollande yönetimine dair eleştiriler, başkanlık seçiminde Sosyalist Parti’nin başarısızlığında ve Macron'un seçilmesinde kendini gösterdi. Bu nedenle Nuit Debout, "her şeyden önce var olan politik boşluğun görünür kılınmasıdır. İnsanlar politikada temsil edilmediklerini düşünüyorlar, arayış içindeler. $\mathrm{Bu}$ temsil edilememe durumu, patlaması halinde sonuçlarının ne olacağını kestiremediğiniz sıkıştırılmış gaza benziyor” (Şakiroğlu, 2016b).

$\mathrm{Bu}$ arayışlarda ortaya konan demokratik kriz, yeni bir siyasal düzen için vatandaşların ortak bir duygu etrafında bir araya gelişini göstermektedir. Bunun için de tartışma kanallarının açık olması, bu açıklı̆̆ın fiziksel olarak da meydanlara taşınması istenmektedir. Nuit Debout örneği, Mayıs ‘68'i hatırlatacak şekilde Paris’te gençlerin ve öğrencilerin başını çektiği bir kitle tarafından ortaya konmuştur. Burada yeniden gençliğin siyasi bir aktör olarak öne çıkması önemlidir. Çünkü neoliberal ekonomik politikaların etkilediği çalışma yaşamı ve işsizlik, gelecekte onları etkileme potansiyeli taşımaktadır. Geleceğe ve bugüne dair duyulan güvensizlik, siyasal alternatif arayışını tetiklemektedir. Diem25 de bu şekilde bir alternatif arayışının sonucu olarak ortaya çıarken bu süreci daha uluslararası platformda yürütme amacı vardır. Yerel sorunlardan ziyade Avrupa siyasetinin ve demokrasinin kendisine odaklanma görülmektedir. Her iki örnek de ekonomik karar alma süreçlerinde halkın etkisinin oldukça düşük olması tespitinden yola 
çıkarak kendi hayatı için daha fazla söz hakkı isteyen bireylerin taleplerini yükseltmektedir. Demokratik talepler, ekonomik işleyişin kolaylaştırıcısı değil belirleyicisi olmak arzusundadır. Avrupa siyasetinin geçmişte olduğu gibi bugün de demokrasi yönünde toplumsal hareketlerin taban baskısıyla yolunu belirleyeceği bir kavşakta bulunmaktadır. Bu taleplerin bastırılması ve görmezden gelinmesi, $\mathrm{AB}$ projesinin kaderini de etkiler. Dolayısıyla liberal demokrasinin krizinin yeni radikal savruluşlara yönelmesi mümkündür. Bu sürecin aşırı-sağın istediği bir dost-düşman çizgisi yerine dayanışmacı bir demokrasi yönüne evrilmesi, bahsedilen taban hareketlerinin gücünü artırmasıyla yakından ilgilidir.

\section{Kuzey Ormanları Savunması}

Türkiyede de kolektif eylemlerde kentin açık alanlarının kullanımının bir protesto repertuarına dönüştüğünün göstergeleri sıklaşmaktadır. TEKEL özelleştirmelerine karşı eylemlerde Ankara’da oluşan çadır-kent, HES’e karşı eylemlerde Cerattepe gibi yerel köy ve kasabalar, kentsel dönüşüme karşı Sulukule başta olmak üzere çeşitli semt mücadeleleri ve tabii ki Taksim’in tarihi önemi, yakın zamanda bu öneme yeni bir anlam katan Gezi Parkı eylemleri, bunların tipik örnekleridir. TEKELHES-Gezi Parkı süreçlerinde eylemlerin bir döngü içinde birbirini destekleyerek dönüştüğü görülebilir (Yıldırım ve Gümrükçü, 2017). Dolayısıyla bir araya gelinen mekanlar, bir araya gelme talebi kadar önem kazanmaktadır. Bu mekanlar ve alanlar, ortak olanın elbirliğiyle değiştirilip korunabileceğini sembolize etmektedirler. Dolayısıyla sıradan insanın siyasal taleplerini sadece seçimler ve temsilciler aracılığıly ifadesine dayanan liberal demokratik temellerin bu mekanlarda yeniden düşünüldüğü ve değiştirildiği görülebilir. Bu eylemlerin çeşitli farklılıklarına rağmen ortak noktaları, demokrasinin sınırlandırılmış ve teknikleştirilmiş, kitlelerden uzaklaştırılmış mantığının yerinden edilmesidir. Diğer bir deyişle Türkiye'de de 2010 sonrası hareketlerde, ortak olanı demokratik şekilde yeniden kurmak üzerine bir eğilim söz konusudur. Bu eğilimin kentsel alanların kullanımında neoliberal mantığın işleyişini durdurmak şeklinde ilerlediği görülebilir.

Gezi Parkı sonrası süreçte kısmen devam ettirilen park forumları ve onunla ilişkili olarak gelişen çevre hareketleri de bu çerçevede ele alınabilir. Örneğin Kuzey Ormanları Savunması (KOS) adıyla gelişen hareket, yukarıda dile getirilen ortak olanı koruma noktası üzerinden ilerlemektedir. Hareket kendini "odak noktası İstanbul'un kuzeyi olmak üzere su havzaları, tarım alanları, çok sayıda endemik bitki ve hayvan türlerinden oluşan farklı ekosistemlerin bir arada bulunduğu bütüncül bir ekolojik alanın varlığını sürdürebilmesini savunmak" şeklinde tanımlamaktadır (kuzeyormanlari.org, 2017). Bu çerçevede tüm canlıları, İstanbul, ülke ve tüm dünya ölçeğinde bir bütün olarak görerek bilgi üretmeye çalıştığını belirten KOS, “özyönetimci bir anlayışı savunur ve bunu öncelikle kendi içinde olmak üzere hayatın her alanında hayata geçirmeye, geliştirmeye çalışır. Buna paralel olarak tüm hiyerarşileri reddeder, dönüşümlü görev dağılımını ve forumlarda kolaylaştırıcılığı benimser”. Bu kavramlar küreselleşme-karşıtı hareket ve Sosyal Forumlar sürecinden bu yana gittikçe güçlenen ve toplumsal hareketler tarafından sahiplenilen unsurlardır. Bunlar, yukarıdan aşağı şekillenen tipik bir örgütlenme ve örgütsel bağlılık yerine 
daha geniş bir çerçeveyi, bireylerin katılımını ve katıldığı yapıyı dönüştürmesini öngörmektedir. KOS’un küresel çapta gelişen bu çizgiyi sahiplendiği görülebilir.

Çarpık kentleşmeyi, kentsel dönüşümün betonlaşmaya dönüşmesini ve kar temelli kalkınma politikalarını eleştiren, küresel ısınmanın olası sonuçları hakkında bilinç yaratmayı amaçlayan KOS, merkeze aldıkları çevre siyasetini sadece çevre hukuku ya da siyasası üzerinden değil, yukarıda belirtilen ortak olanı siyasal olarak kurmak hassasiyeti üzerinden yürütmektedir. $\mathrm{Bu}$ konularda gündem yaratma kapasitesi, benzer konularda hassasiyetleri olan kurum ve hareketlerle iş birliği şeklinde ilerlemektedir. Bu sadece 1990'lara damga vuran bir sivil toplum faaliyeti ve bu çerçevede gelişen çeşitli projeler üretmek boyutunda sınırlı kalmamaktadır. Konu daha geniş bir çerçevede, siyasetin köklü bir eleştirisine dayandırılmaktadır. Hareketlerin kuracağı koalisyonlar ve yaratacağı dayanışma ağları, hedeflenen etkiyi yaratma konusunda oldukça önemlidir. Özellikle kentleşme ilgili konularda farklı dinamiklerin bir arada düşünülmesi ve mücadelenin bütüncül bir şekilde yürütülmesi vurgulanmaktadır (Baysal, 2017).

Birey-devlet ilişkisini şekillendiren vatandaşlık, çeşitli örnekler kendini gösterdiği gibi kamusal alanı kuracak aktif bir dinamizm olarak öne çıkar (Kaya, 2017). Vatandaşlık ortak bir paylaşımı ifade eder. Özü itibariyle kültürel ve hukuki temellere dayansa da yeni dönemde bu paylaşımın genişletilmesi, mekânsal düzeyde kurulacak bağlarla mümkündür. Bireylerin yaşadığı alana dair söz söyleme kapasitesinin artması, onu aktif vatandaşlığa yaklaştıracaktır. Böylece demokrasinin alanı da genişler. Sivil ve barışçıl bir siyasetin önünü açacak olan bu alanların, çeşitli konulardaki hasımlarıyla çekişmeleri de siyasal hayatı şekillendiren unsur olacaktır. Böylece kentsel yaşama müdahale ve ortak olanı şekillendirme düşüncesiyle, yukarıda değinilen şehir hakkı düşüncesine temas etmek mümkündür.

Gerek HES-karşıtı protestolarda, gerekse Kuzey Ormanları Savunması’nda görülebileceği gibi kent sakinleri, kendi yaşam alanlarını korumak adına ortak bir noktada buluştuğu diğerleriyle kurdukları etkileşimle beraber, yeni bir birliktelik kurmaktadır. Bu birliktelik, ne klasik toplulukların birincil ilişkilerine sahiptir ne de halk yaratma sürecindeki büyük hedeflere sahiptir. Bunların yerine ortak yaşamı, girişte değinildiği gibi, bir sabitliğe erişmeden ama çeşitli ortak noktaları artırarak ve yeniden yaratarak ele almaktadır. Yeniden yaratım süreci, herhangi bir önkabul, ilksel-doğru ya da manifestodan ziyade yaparak öğrenmeye dayanmaktadır. Takip edilen temel doğru, neoliberalizmin kar mantığının ve hesap-vermez (unaccountable) yukarıdan kararalıcılığının sorgulanmasıdır. Özelleştirmeye karşı direnerek farklı kentlerden aileleriyle birlikte bir sokakta toplanan TEKEL işçilerinin kurdukları çadırların birbiriyle bağlanması da benzer bir sembolizmi karşılar, s. Farklılıkların birliğini paylaşılan ortak doğrular etrafında bir araya gelmiş ve bağlanmış bir çadır-sokağı. İspanya’da Podemos’u, Yunanistan'da Syriza’yı yaratan, Fransa'da Nuit Debout'yu oluşturan durum da buna benzerdir: Kendi yaşamına, gündelik hayatına doğrudan temas eden konularda karar-verme mekanizmasını yine aynı şekilde değiştirmeye çalışma ve bunu kentsel alanları paylaşarak duyurmak. Kentin meydanları, sokakları, parkları gibi ortak yaşamı sembolize eden yerler bu eylemlerde kritik önemdedir. Çünkü demokrasi bu açıklığı ve bir aradalığı içinde barındırır. Konuşma ve tartışma siyasal eylemin kurucu noktaları olarak bu 
alanlarda rahatça işler. Tabandan işleyen bir siyasallaşma ve konuşma pratiği, demokratik siyasetin dayanması gereken temel unsurlardır. Kentsel hareketlerde sıradan insanın bu firsatları bularak diğerleriyle bir etkileşime girebilmesi, birlikte yaşamın ortak noktalarını bulmak açısından bu hareketlerin etkisini gün geçtikçe artırmaktadır. Bu hareketlerde belli bir konu ya da talep, ortak olanı düşünmek ve somutlaştırmak açısından işlerlik kazanır. Amaç sadece o konunun ya da sorunun çözülmesi değil, ortak yaşamı kuracak müştereklerin de düşünülmesidir.

Dolayısıyla bir barajın protesto edilmesi, bir inşaatın durdurulması ya da yolun başka yerden geçmesi talebi esasen birlikte yaşamın şekillendirilmesi meselesidir. Burada başta o yörede yaşayanlar olmak üzere herkesin ilgilendiren ve kimsenin üzerinde tek başına söz sahibi olamayacağı alanların birlikte gözden geçirilmesi düşüncesi yatar. Bu şekilde uygulanan doğrudan demokrasi, temsilcilerin ve devletin bir amaç olmaktan öte araca dönüşmesini sağlar. Ortak olanı şekillendirmek bu aracilara kimi konularda görev verir, yetkilendirir. Kentsel alanlar başta olan üzer ortak yaşam alanların şekillenmesinde piyasanın ve metalaşmanın öncü mantığı bu şekilde geride birakılabilir.

\section{Sonuç}

Girişte belirtilen siyasal olanın ortak olanı yeniden kurmak için yaratıcı ve kurucu bir eylem olarak düşünülmesi durumunu bahsi geçen örneklerdeki pratiklerde görmek mümkündür. $\mathrm{Bu}$ örneklerde çeşitli farklılıklara rağmen ortak nokta, siyasal söylemleri açık alanlarda dillendirmek ve yaşamsal alanları aktif biçimde kullanarak dinamik şekilde duyurmak düşüncesidir. Esasen bu eğilim, gittikçe güçlenen ve küreselleşen bir siyaset yapma biçimine dönüşmektedir. 2000’lerin başından beri bu siyaset pratiği, yeni alternatiflerin aranması ve siyasetin eski tipik kurumların, araçların ve kavramların ötesinde yeniden düşünülmesini sağlamanın önünü açmıştır. Sosyal Forum süreçlerinde şekillenen bu tartışmalar, geçen 20 yılda güçlenerek devam etmektedir. Kimi eski kavramların yeniden ele alınması neoliberal alternatifsizliğin önüne geçmek noktasında atılan adımları göstermektedir. Nuit Debout, Diem 25 ve Kuzey Ormanları Savunması gibi oluşumlar bu düşüncenin örneklerini oluşturur. Bu örnekler, kurucu bir siyasetin ortak olanı yeniden kurmaktan geçtiğini gösterir. Ortak olanı bir ideoloji ya da siyasal çerçeveye dayandırmadan kentsel hayatın içinde gündelik ilişkileri kar hedefinin ötesinde yeniden düşünmek, bu hareketlerin ortak noktasıdır.

Yukarıdaki teorik açılımlarda da değinildiği gibi, bireysel olanla kamusal arasındaki bağı kurmakta öne çıkan kentsel zeminler, demokrasinin teorisi ile pratiğinin de buluştuğu alanlardır. Ortak olanı sadece coğrafi ve fiziksel paylaşımların ötesinde siyasal bir tartışmanın zemini olarak da ele almak, kurulacak alternatifleri daha geniş şekilde düşünmeyi sağlar. Alternatif, var olan başka bir kalıbı kullanmak değil, ortak olanı yeniden kurarak ortaya çıkacaktır. Kentsel alanlar bu açıdan hem somut hem de teorik çabaları göstermek açısından önemlidir. Şehir hakkının çizdiği çerçevede kentsel alanları birlikte korumak, kullanmak ve ticaretten önce sosyal olanın kullanımına açmak yönündeki girişimler, kamusal alan ve vatandaşlık gibi kavramları yeniden düşünülebilir 
kılar. Demokrasi burada kurucu çerçeveyi oluşturur. Bireylerin karar-alma mekanizmalarına müdahalesini kolaylaştırmak açısından demokrasiyi kentsel alanların korunması ve ortak olanın şekillendirilmesi boyutlarıyla düşünmek, son dönem siyasal teorinin temel tartışmalarındandır. Bu noktada bireyler, yaşadıkları alanlara müdahale ederek yeni bir demokrasi tartışmasının önünü açarlar. Bu önerinin daha önceki katılımcı demokrasi gibi kavramlardan temel farkı, siyaseti kurumsal olanın ya da cumhuriyetçi bir birliğin kurulmasından ötesinde düşünmesidir. Bu noktada otonomi kavramı, açık ve kentsel alanlar devreye girer. Açık alanlarda ifade edilen talepler hem yaşanılan çevreyi hem de siyasal sistemi dönüştürücü potansiyellere sahiptir. Yukarıda değinilen örnekler bu potansiyellerin uygulamaya konduğu girişimlerdir. Ortak olanı şekillendirecek pratikleri ve dinamizmi geliştirmeden onu koruyacak bir hukuk düzeni kurmak, halihazırda var olan çerçeveyi aşarak ortak yaşamın pratiğini şekillendirmekle ilgilidir. $\mathrm{Bu}$ sürecin devamında da siyaset, piyasanın kurallarına boyun eğen bir çizgide takılı kalmaktan kurtulacaktır. Siyasetin köklerini sorgulamak, ortak olanı yeniden kurmak ve bunu da kolektif eylemlerin birbiriyle kuracağı temaslara dayandırmaktır. 


\section{Kaynakça}

Agustin, O. G. (2015). The Common and Its Potential Creativity: Post-Crisis Perspectives. In Giuseppe Cocco, Barbara Szaniecki (Eds.), Creative Capitalism, Multitudinous Creativity, Radicalities and Alterities (pp.43-60). Lanham: Lexington Books.

Agustin, O. G. (2017). European Counterpublics? DiEM25, Plan B and the Agonistic European Public Sphere. Journal of Civil Society, 13(3), 323-336.

Badiou, A. (2015). Yunanistan’ın Kaderine Dair 11 Melankolik Madde. http://meseledergisi.com/2015/10/ yunanistanin-kaderine-dair-11-melankolik-madde-alain-badiou/, 06.10.2015, Erişim: 22.01.2018.

Baysal, E. (2017). Terricide: Poisoning the Lungs of Istanbul. Research and Policy on Turkey, 2(1), 10-24, DOI, s. 10.1080/23760818.2016.1272264

Brand M., Gupta A. (2016). What is the 'Nuit Debout'?, http://www.counterpunch.org/2016/05/03/what-isthe-nuit-debout/, Erişim: 01.10.2016

Birnbaum B. (2016). Daha Önce Görülmemiş Bir Toplumsal Hareket Fransa'da Bir Siyasi Krizi Nasıl Tetikledi?. http://baslangicdergi.org/daha-once-gorulmemis-bir-toplumsal-hareket-fransadabir-siyasi-krizi-nasil-tetikledi-benjamin-birnbaum/, (Çev. Görkem Doğan), 03.07.2016, Erişim. 22.01.2018.

Butler, C. (2012). Henri Lefebvre: Spatial Politics, Everyday Life and the Right to the City. New York: Routledge Cahill, D., \& Konings, M. (2017). Neoliberalism. New York: John Wiley \& Sons.

Carnoy, M. (2014). The State And Political Theory. Princeton University Press.

Chatterton, P. (2017). Kent Müştereğini Aramak. F. Adaman, B. Akbulut, U. Kocagöz (Haz.), Herkesin, Herkes İçin içinde (s. 202-208). İstanbul: Metis Yayınları.

Curcio, A. (2010). Translating Difference and the Common. Rethinking Marxism, 22(3), 464-480.

Crouch, C. (2004). Post-Democracy. Cambridge: Polity Press.

De Angelis, M. ve Harvie D. (2017). Müşterekler. Fikret Adaman, Bengi Akbulut, Umut Kocagöz (Haz.), Herkesin, Herkes İ̧̧in içinde (s. 105-128), İstanbul: Metis.

Della Porta, D. (2015). Social Movements in Times of Austerity. Cambridge: Polity.

Diem25.org (2016). Manifesto. https://diem25.org/manifesto-short-version/, Erişim: 30.09.2016.

Dikeç, M. (2015). Space, Politics and Aesthetics. Edinburgh: Edinburgh University Press.

Douzinas, C. (2015). Krizde Felsefe ve Direniş. (Çev. Tulga Buğra Işık), İstanbul: Metis Yayınları.

Erdi-Lelandais, G. (2014). Lefebrve's Legacy: Understanding the City in the Globalisation Process. In G. Erdi-Lelandais (Ed.), Understanding the City: Henri Lefebvre and Urban Studies (s. 1-15). Cambridge.

Gerbaudo, P. (2017). The Mask and the Flag: Populism, Citizenism and Global Protest. New York: Oxford.

Gidwani, V. \& Baviskar, A. (2017). Kentsel Müşterekler. F. Adaman, B. Akbulut, U.Kocagöz (Haz.), Herkesin, Herkes İçin içinde (s. 198-201). İstanbul: Metis Yayınları.

Gigi, R. (2010). Five Theses on the Common. Rethinking Marxism, 22(3), 357-373.

Hardt, M. \& Negri, A. (2004). Çokluk. (Çev. Barış Yıldırım), İstanbul: Ayrıntı Yayınları.

Harvey, D. (2005). Neoliberalizmin Kısa Tarihi. (Çev. Aylin Onacak), İstanbul: Sel Yayınları.

Harvey, D. (2008). Umut Mekanları. (Çev. Zeynep Gambetti), İstanbul: Metis Yayınları.

Harvey, D. (2013). Asi Şehirler - Şehir Hakkından Kentsel Devrime Doğru. (Çev. Ayşe Deniz Temiz), İstanbul: Metis Yayınları.

Haski, P. (2016). Nuit Debout Protests Are Confirmation That France's Political System is Broken. https:// www.theguardian.com/commentisfree/2016/apr/13/nuit-debout-france-occupy-wall-street-1968, 13.04.2016, Erişim: 14.10.2017. 
Jessop, B. (1990). State Theory: Putting The Capitalist State in Its Place. Penn State Press.

Jessop, B. (2016). State Theory. In C. Ansell, J. Torfing (Eds.), Handbook on Theories of Governance, (pp. 7185). Elgar Publishing.

Kuzeyormanlari.org (2017). Kuzey Ormanları. http://www.kuzeyormanlari.org/kuzey-ormanlari/, Erişim: 01.10.2017.

Kaya, A. (2017). Right to Public Space: Social Movements and Active Citizenship in Turkey. Research and Policy on Turkey, 2(1), 1-9, DOI, s. 10.1080/23760818.2016.1272273.

Lefebvre, H. (1996). The Right to the City. Writings on Cities (pp.147-159). Oxford: Blackwell Publishing.

Parker, S. (2011). Cities, Politics \& Power. New York: Routledge.

Pescinski, J. (2016). The Common Humanity Of Nuit Debout. https://www.opendemocracy.net/ mediterranean-journeys-in-hope/janina-pescinski/common-humanity-of-nuit-debout, 03.06.2016, Erişim: 15.10.2017.

Pleyers G. (2016). Nuit Debout: Citizens Are Back in The Squares in Paris. https://opendemocracy.net/ geoffrey-pleyers/nuit-debout-citizens-are-back-in-squares-in-paris, 08.04.2016 Erişim: 02.10.2016

Purcell, M. (2008). Recapturing Democracy: Neoliberalization and the Struggle For Alternative Urban Futures. New York: Routledge.

Purcell, M. (2013). The Down-Deep Delight Of Democracy. New York: John Wiley \& Sons.

Radnor, Z. \& Osborne, S. \& Glennon, R. (2016). Public Management Theory. In C. Ansell, J.Torfing (Eds), Handbook on Theories of Governance (pp. 46-60), Elgar Publishing.

Ranciere, J. (2007). Siyasalın Kıyısında. (Çev. Aziz Ufuk Kılıç), Metis Yayınları, İstanbul

Roos, J. E. \& Oikonomakis, L. (2013). We are Everywhere! The Autonomous Roots of the Real Democracy Movement. http://roarmag.org/2013/08/autonomous-roots-real-democracy-movement/, Erişim: 03.07.2017.

Sönmez, P. D. (2015). Kronik: Umudun Çocuklarından Avrupa Sosyalizmine: SYRİZẢnın Büyük Zaferi. Ankara Üniversitesi SBF Dergisi, 70(1).

Springer, S., Birch, K., \& MacLeavy, J. (Eds.). (2016). The Handbook of Neoliberalism, New York: Routledge. Stavrides, S. (2016). Common Space: The City as Commons, Zed Books.

Stavrides, S. (2017). Brezilya Kent Hareketleri. F. Adaman, B. Akbulut, U. Kocagöz (Haz.), Herkesin, Herkes İçin içinde (s. 239-249), İstanbul: Metis Yayınları.

Swyngedouw, E. (2011). Interrogating Post-Democratization: Reclaiming Egalitarian Political Spaces. Political Geography, 30(7), 370-380.

Şakiroğlu, S. (2016a). Fransảda 'Bilek Güreşi' ve 'Solun Kimliğii. http://bianet.org/bianet/emek/175300fransa-da-bilek-guresi-ve-solun-kimligi, 30.05.2016, Erişim, 22.01.2018.

Şakiroğlu, S. (çev.) (2016b). Fransa: 'Gece Ayakta' ve 'Popülist Hareket.' https://bianet.org/bianet/ siyaset/175657-fransa-gece-ayakta-ve-populist-hareket, 09.06.2016, Erişim: 22.01.2018.

Tr.euronews (2016). Nuit Debout 'Gece Ayakta' Hareketi Fransa Halkının Sesi Oldu. http://treuronews. com/2016/06/17/nuit-debout-gece-ayakta-hareketi-fransa-halkinin-sesi-oldu, 17.06.2017, Erişim: 15.10.2017.

Varoufakis, Y. (2017). We Need An Alternative To Trump's Nationalism. It Isn't The Status Quo. https:// www.theguardian.com/commentisfree/2017/jan/22/trumps-nationalism-response-not-globalization, 22.01.2017, Erişim: 18.10.2017.

Varufakis, Y. (2015). Küresel Minotaurus. (Çev. Ferhat Kohen), Encore Yayınları, İstanbul. 
Wadham, Lucy (2016). French Take To The Barricades To Protect Their Way Of Life. https://www. theguardian.com/commentisfree/2016/may/14/france-paris-nuit-debout-protests-may-1968, Erişim: 14.10.2017.

Wood, P. B. (2017). Citizenship, Activism and the City: The Invisible and the Impossible. London: Routledge.

Yates, L. (2015). Everyday Politics, Social Practices And Movement Networks: Daily Life In Barcelona's Social Centres. The British Journal of Sociology, 66 (2), 236-258.

Yıldırım, Y. (2013). Sosyal Forum'dan Öfkeliler'e, İstanbul: İletişim Yayınları.

Yıldırım, Y. (2015). Avrupalı Toplumsal Hareketlerin Yükselişi: 2012-2014 Arası Kurulan Birliktelikler. Ankara Üniversitesi SBF Dergisi, 70(4), 983-1002.

Yıldırım, Y. ve Gümrükçü, S. B. (2017). Tekel-HES ve Gezi Parkı Protestoları Ekseninde Türkiye’de Eylem Dalgalarının Sürekliliği ve Değişimi. Pamukkale Üniversitesi Sosyal Bilimler Enstitüsü Dergisi, Sayı 26, 388-405.

Yıldız, O. (2015). Popülist İtirazdan Popülist İdareye: SYRIZA ve PODEMOS Örnekler. Mülkiye Dergisi, 39(2), 291-296.

Zevnik, A. (2015). Maze of Resistance: Crowd, Space and the Politics of Resisting. Globalizations, 12(1), 101-115. 